\title{
Impact of the 2009 extreme water level variation on phytoplankton community structure in Lower Amazon floodplain lakes
}

Impacto da variação extrema do nível da água em 2009 sobre a estrutura

da comunidade fitoplanctônica de lagos da planície do Baixo Amazonas

\author{
Simone Casali ${ }^{1}$, Maria do Carmo Calijuri ${ }^{1}$, Bernard Barbarisi ${ }^{2}$, \\ Vivian Fróes Renó ${ }^{2}$, Adriana Gomes Affonso², Cláudio Barbosa², \\ Thiago Sanna Freire Silva ${ }^{2}$ and Evlyn Márcia Leão de Moraes $\mathrm{Novo}^{2}$
}

${ }^{1}$ Departamento de Hidráulica e Saneamento - SHS, Escola de Engenharia de São Carlos - EESC, Universidade de São Paulo - USP, Av. Trabalhador São-Carlense, 400, CEP 13566-590, São Carlos, SP, Brazil e-mail: spcasali@yahoo.com.br; calijuri@sc.usp.br

${ }^{2}$ Divisão de Sensoriamento Remoto, Instituto Nacional de Pesquisas Espaciais - INPE, Av. dos Astronautas, 1758, CEP 12227-010, São José dos Campos, SP, Brazil e-mail: bernard@dsr.inpe.br; vivian@dsr.inpe.br; affonso@dsr.inpe.br; claudio@dpi.inpe.br; thiago@dsr.inpe.ca; novo@dsr.inpe.br

\begin{abstract}
Aim: This paper examines the effect of the extreme water level change in 2009 on the structure and diversity of the phytoplankton communities in lakes of the Lower Amazon Floodplain, and compares it to phytoplankton community structure data reported in the literature for 2002 and 2003 high water periods, closer to the normal hydrological conditions. Methods: Sub-surface integrated water samples for phytoplankton and chlorophyll- $a$ analyses were collected during high and low water phases in 2009. Water temperature $\left({ }^{\circ} \mathrm{C}\right), \mathrm{pH}$, turbidity $(\mathrm{NTU})$ and electrical conductivity $\left(\mu \mathrm{S} . \mathrm{m}^{-1}\right)$ were measured, and the Shannon diversity index was calculated. Results: The results showed striking differences in taxonomic composition between phases (high and low) and also between normal (2002 and 2003) and extreme (2009) hydrological conditions, all related to the flood pulse intensity. Conclusions: Extreme water level fluctuations can result in shifts in phytoplankton community structure and diversity. This work represents a valuable contribution to phytoplankton research since presents the community structure under extreme hydrological events in the Amazon floodplain.
\end{abstract}

Keywords: phytoplankton, Amazon floodplain, extreme hydrological events.

Resumo: Objetivo: Esse trabalho investiga o efeito da extrema variação da mudança do nível da água em 2009 na estrutura e diversidade das comunidades de fitoplâncton nos lagos da planície de inundaçáo do Baixo Amazonas,e compara estes resultados à estrutura da comunidade de fitoplâncton reportada na literatura para os períodos de água alta em 2002 e 2003, próximos a condiçōes hidrológicas normais. Métodos: Amostras de água da sub-superfície foram coletadas para a análise de fitoplâncton e clorofila-a nos períodos de água alta e baixa em 2009. Temperatura da água $\left({ }^{\circ} \mathrm{C}\right), \mathrm{pH}$, turbidez (NTU) e condutividade elétrica $\left(\mu \mathrm{S} . \mathrm{m}^{-1}\right)$ foram medidas, e o índice de diversidade de Shannon calculado. Resultados: Os resultados revelaram diferenças marcantes na composição taxonômica entre fases da inundação (alta e baixa) e também entre eventos hidrológicos normais (2002 e 3003) e extremos (2009), todos relacionados com a intensidade do pulso de inundação. Conclusóes: Flutuações extremas do nível da água podem resultar em alteraçóes na estrutura da comunidade e na diversidade. Esse trabalho é uma contribuição valiosa a pesquisa em fitoplâncton, pois apresenta a estrutura da comunidade sob condiçóes hidrológicas extremas na planície de inundação Amazônica.

Palavras-chaves: fitoplâncton, planície de inundação Amazônica, eventos hidrológicos extremos. 


\section{Introduction}

In the Amazon floodplain wetlands, the yearly succession of high and low water levels (the "flood pulse", sensu Junk et al., 1989) is the main driving force controlling the hydrological and ecological processes in lakes. Properties such as flooded area, flood duration, lake connectivity and water residence time are all largely determined by the water level in the main rivers (Junk, 1997; Bonnet et al., 2008). These processes, in turn, will control the energy and nutrient exchanges between the river and the floodplain lakes, and by extension regulate the structure, diversity and productivity of the floodplain biota, including phytoplankton communities (Henry et al., 2006; Junk and Piedade, 1997; Wittmann et al., 2006; Silva et al., 2010).

The Amazonian phytoplankton communities are composed of several species, each having different environmental requirements and physiological, morphological and phenological characteristics (Kruk et al., 2010). Phytoplankton community structure, for example, responds to variations in solar radiation, water temperature, mixing dynamics, and nutrient and light availability (Winter et al., 2011). Moreover, several studies have documented changes in the structure and functioning of phytoplankton communities in response to water level changes (Ibanez, 1998; Junk et al., 1989; Roland et al., 1997; Nabout et al. 2006; Loverde-Oliveira and Huszar, 2007).

Nogueira et al. (2010) documented phytoplankton biodiversity in lakes of the lower Amazon, by sampling during two consecutive high water periods in 2002 and 2003. They hypothesized that beta diversity would be similar for both years, given the similar precipitation patterns observed during each sampling. The authors, however, concluded that neither environmental nor spatial factors explained a significant proportion of the total variation in phytoplankton community structure. though the results were similar in both years. They suggested that other local environmental variables, not measured during the study, could be relevant to the structure of phytoplankton communities (e.g. water residence time and mixing patterns, among others).

The water stage heights registered for the Amazon River at the Óbidos gauging station for the years 2002 and 2003 show that, despite the similar precipitation patterns, inundation levels were quite different between these years (Figure 1). This can be explained by the fact that the Amazon flood pulse is determined by the cumulative amount

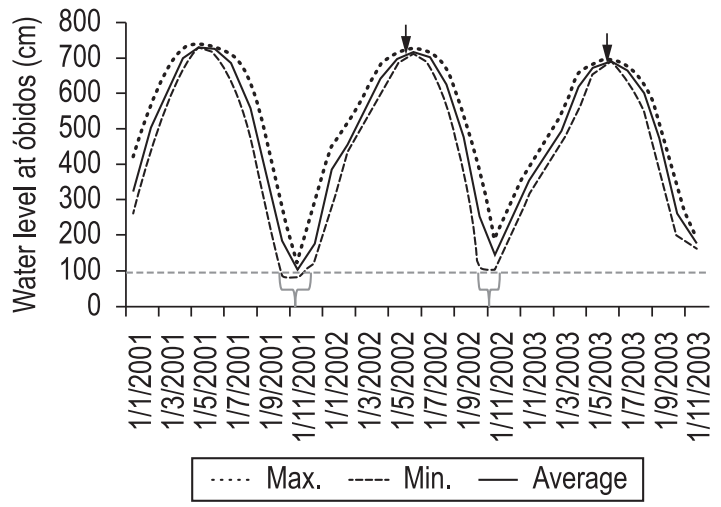

Figure 1. Amazon flood pulse dynamics from 2001 to 2003, for the Óbidos gauging station (Pará, Brazil). Red arrows show sampling dates for Nogueira et al. (2010). The blue dotted line marks the minimum water level in 2002; blue brackets define the duration of the low water period.

of precipitation throughout the entire basin, and especially on its headwaters in the Andes, and thus much less affected by local precipitation events (Junk, 1997; Bonnet et al. 2008).

The low water phase preceding the 2002 sampling by Nogueira et al. (2010) was longer, and reached lower levels when compared with the following year, which could explain the differences in species diversity recorded for the high water period of each year. Lower water levels preceding the high water sampling could have affected several processes that control phytoplankton growth and diversity; as most Amazon floodplain lakes are quite shallow, wind-induced mixing can significantly alter turbulence and turbidity, and thus nutrient and light availability (Alcântara, 2006). The differences observed by Nogueira et al. (2010) could therefore be more related to flood pulse dynamics than to dilution effects caused by precipitation.

The annual flood pulse is a predictable event for the Amazon river-floodplain ecosystems (Junk et al., 1989; Junk, 1997), and for the relatively undisturbed ecosystems of the Upper Amazon floodplain, the phytoplankton communities will show adaptation strategies that reflect these cyclical changes. However, at more heavily disturbed environments such as the Lower Amazon floodplain, these adaptation strategies may be disrupted. Several authors have identified the occurrence of intense human use activities in the lower Amazon floodplain, such as agriculture, forest logging and cattle ranching, since the beginning of the $20^{\text {th }}$ century (McGrath et al., 2007; Roosevelt, 2000; Sheikh et al., 2006; Winklerprins, 2006). A 
large portion of the mature floodplain forest cover in the lower floodplain region has been removed during the last 30 years (Renó, 2010), which could affect the duration, height and velocity of the flood wave (Wittmann et al., 2006; Straatsmaa and Middelkoop, 2007; Bates et al., 2003).

In 2009, the Amazon River underwent the second largest flood event of the past hundred years, which was followed by a severe dry period almost as low as the 2005 and 2010 extreme drought events observed in the region (Marengo et al., 2011). This extreme flood event was particularly severe in the Lower Amazon River Basin, with the Amazon River stage height at Óbidos station reaching almost twice the historical average height, and displaying positive anomalies during the flooding, high and receding phases of the hydrograph and a negative anomaly during the low water level (Figure 2). Moreover, water level change rates were twice as large from the historical averages for both rising and receding levels, with a rising rate of $0.8 \mathrm{~m} . \mathrm{month}^{-1}$ in 2009 compared to the historical average of $0.4 \mathrm{~m}$. month $^{-1}$, and a decreasing rate of $0.9 \mathrm{~m} . \mathrm{month}^{-1}$ in 2009, against $0.39 \mathrm{~m} . \mathrm{month}^{-1}$ for the historical averages. As surrogates of flow velocity, these rates indicate that hydrodynamic factors such as turbulence, erosion power, among others are also likely to have changed between periods.

Given the above, the present paper further examines the effect of water level changes on phytoplankton community structure, by assessing the observed effects of the extreme changes in water level observed for the year 2009 on the structure and diversity of the phytoplankton communities in lakes of the Lower Amazon Floodplain. This paper also compares the phytoplankton community structure observed during 2009 to the data reported by Nogueira et al. (2010) for the two high water periods closer to the normal hydrological conditions.

\section{Material and Methods}

\subsection{Study area}

The study area includes several lakes located along the Lower Amazon River mainstem, from the town of Parintins (Amazonas State) to the town of Almeirim (Pará state) (Figure 3). This region has a long history of human use and disturbance; almost $50 \%$ of the mature forest cover has been removed in the last 30 years (Renó, 2010), with a corresponding threefold increase in total herd size (cattle and buffalo) (Barbarisi, 2010). Previous

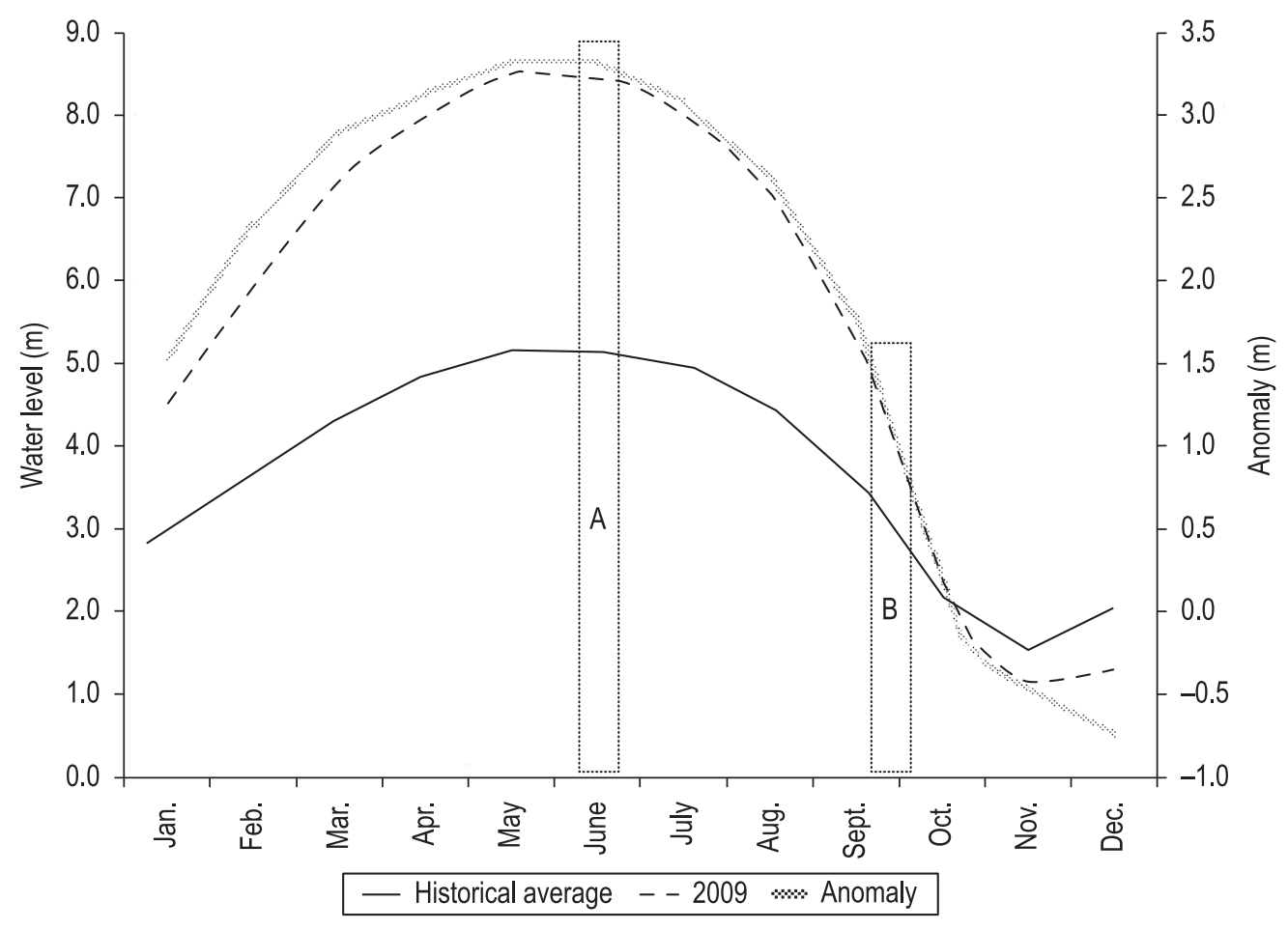

Figure 2. Amazon water level fluctuation measured at the Óbidos gauging station (Pará, Brazil), showing the monthly historical average (1970-2010), the monthly average for 2009, and the water level anomaly (2009 minus historical average). Black dashed boxes indicate sampling periods: a) high water, from June 10 to June 26, 2009; and b) receding water period, from September 22 to October 1, 2009. 


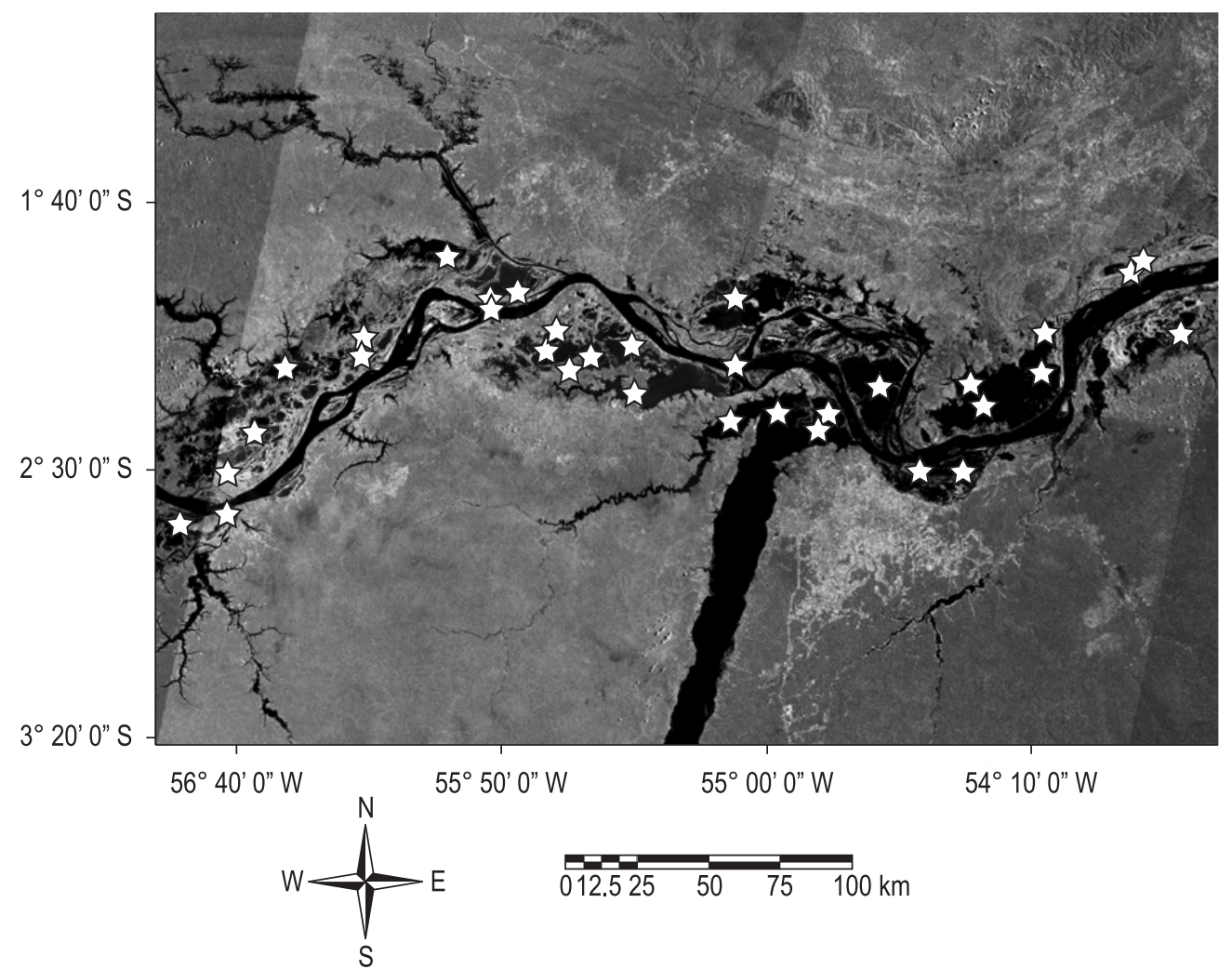

Figure 3. Study area (Lower Amazon floodplain, Brazil), showing the distribution of sampling points. The area includes the major confluence of the Amazon and Tapajós rivers (at approximately $55^{\circ} \mathrm{W}$ and $2^{\circ} 30^{\prime} \mathrm{S}$ ).

studies of floodplain lakes in this region reported high chlorophyll-a concentrations throughout the hydrological year, which could be related to eutrophication caused by intensive cattle ranching (Barbosa, 2005; Novo et al., 2006; Barbosa et al., 2010; Affonso et al., 2011).

\subsection{Data collection}

Sampling sites were distributed along the study region, in various floodplain lakes on both the north and south river banks (Figure 3). Limnological data were collected at two different periods, corresponding to extreme water levels according to the Óbidos gauging station: June $10^{\text {th }}$ to June $26^{\text {th }}$, 2009 (high water), and September $22^{\text {nd }}$ to October $1^{\text {st }}, 2009$ (low water). The lowest water period was avoided due to the increased difficulty in accessing sampling sites. Fluctuations in water level $(75 \mathrm{~cm}$ in the receding water) during each sampling period were considered negligible for the proposed study (less than $10 \%$ of the total 2009 amplitude).

During the high water mission, GPS coordinates were acquired for each of the sampling points, to ensure that the same lakes would be sampled during the low water period. Sub-surface integrated water samples for phytoplankton quantitative analyses were collected using $100 \mathrm{~mL}$ dark flakes immediately fixed in Lugol solution and stored in the dark under refrigeration (Vollenweider, 1974). At the same time, water temperature $\left({ }^{\circ} \mathrm{C}\right)$, $\mathrm{pH}$, turbidity (NTU) and electrical conductivity $\left(\mu S . \mathrm{m}^{-1}\right)$ were measured using a portable YSI 6600 sonde. Water transparency was estimated from Secchi disk depth measurements, and the euphotic zone depth $\left(\mathrm{Z}_{\text {euf }}\right)$ was calculated by multiplying the water transparency by three (Cole, 1975). Water samples were also collected for determination of chlorophyll-a concentrations according to Nush (1980).

Phytoplankton identification was carried out using an inverted Zeiss microscope. Population counts were obtained by the settling technique based in Uthermöhl (1958) with a sample volume varying from 2 to $10 \mathrm{~mL}$, depending on sample organism concentration. The minimum sedimentation time was set as 3 hours (Wetzel and Likens, 1991). The individuals were enumerated in random fields (Uhelinger, 1964) and about 100 individuals of the most frequent species were counted with less than $20 \%$ error, at a confidence level of $95 \%$. 
Phytoplankton organism density (ind. $\mathrm{mL}^{-1}$ ) was calculated according to APHA (2005). The Shanon diversity index was the calculated according to Odum (1988) (Equation 1):

$\mathrm{H}^{\prime}=-\sum_{\mathrm{i}=1}^{\mathrm{s}}\left(\mathrm{p}_{\mathrm{i}} \ln \mathrm{p}_{\mathrm{i}}\right)$

were $S$ is the total number of species, and $p_{i}$ is the counted number of individuals for species $i$.

The same variables were acquired for the same lakes during the low water season, with the exception of lakes that could not be accessed due to the low water level. The final sample size was $n=31$ for the high water sampling, and $n=28$ for the low water sampling.

Climate data were provided by the National Meteorological Institute (Instituto Nacional de Meteorologia) (http://www.inmet.gov.br/), and included monthly average air temperature, monthly rainfall, and total hours of insolation per month, the latter used as proxy for irradiance (INMET, 2010).

\section{Results and Discussion}

All climate variables showed visible patterns during 2009. The monthly precipitation preceding the sampled high water season was higher than the climatologic normal, with an accumulated total precipitation from January to June of approximately $1600 \mathrm{~mm}$ (200 mm higher than the climatologic normal (Figure 4). However, total precipitation preceding the low water season, from July to early September, was $100 \mathrm{~mm}$ below the climatologic normal. The number of insolation hours during the high water season was approximately one third of that during low water season.
Water transparency had the largest differences observed between the two extremes of the water level (Table 1). During the high water season, Secchi depth was almost twice as high as during the low water season. Turbidity values followed the expected inverse pattern of water transparency, with minimum values during high water and maximum during the low water season. Chlorophyll-a concentration was higher during the low water phase $\left(29.7 \mu \mathrm{g} . \mathrm{L}^{-1}\right)$, likely contributing to the reduction of water transparency and euphotic zone depth. The low water period also had the highest observed number of sunny hours (cloud-free days), which may have contributed to phytoplankton production, and consequently to the increase in chlorophyll concentration, dissolved oxygen saturation $(134 \%)$ and $\mathrm{pH}$ values (Table 1).

\subsection{Phytoplankton community structure}

The species counting and identification revealed striking differences in taxonomic composition between the high and low water seasons (Table 2). During high water, 27 taxa were identified, distributed among Chlorophyceae, Bacillariophyceae and Cyanophyceae, whereas 61 taxa were identified during low water, distributed among Chlorophyceae, Cyanophyceae, Bacillariophyceae, Cryptophyceae, Chrysophyceae and Euglenophyceae. Total number of taxa considering both periods was 72 , three times smaller than the number reported by Ibanez (1998) for Camaleão Lake (262 taxa), located in an island of the Solimóes River, $500 \mathrm{~km}$ upstream from our study site. It was also smaller than the 203 taxa reported by Melo and Huszar (2000)

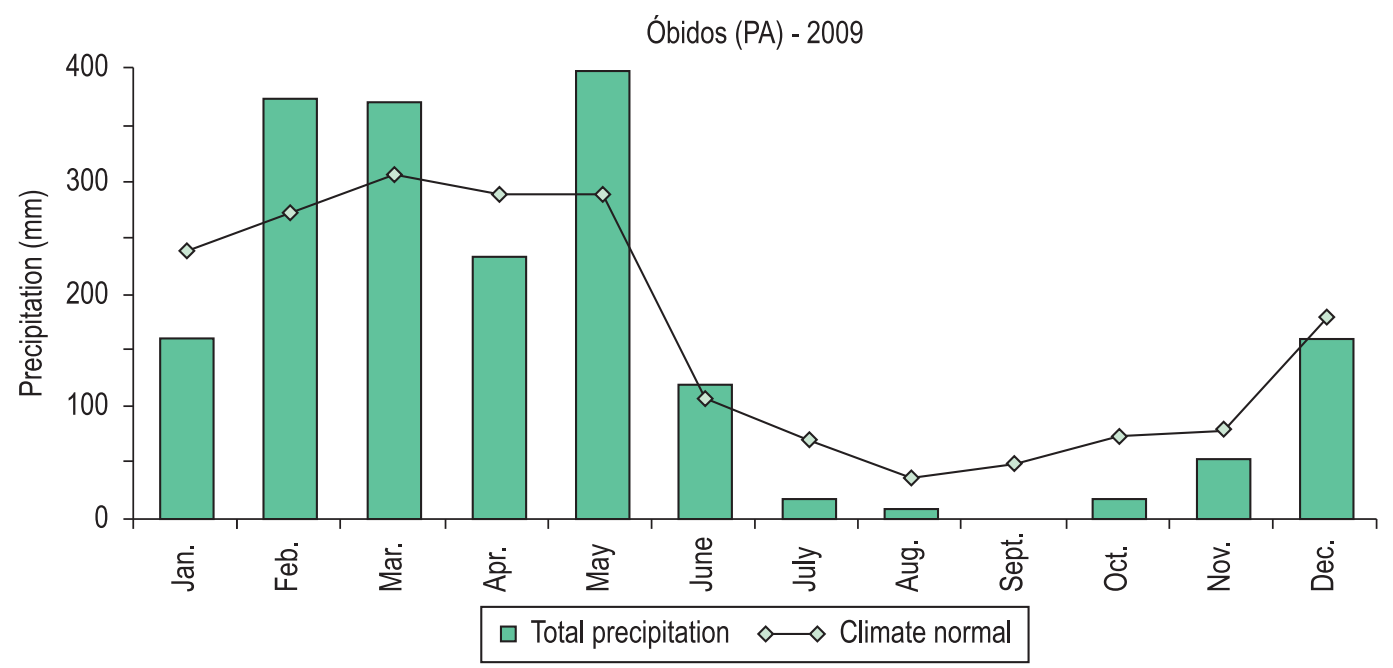

Figure 4. Precipitation for the year 2009 compared to the climatologic normal for Óbidos (Pará, Brazil) (INMET, 2011). 
Table 1. Environmental data observed during phytoplankton sampling at the Lower Amazon Floopldain (Brazil). Values indicate water column averages and standard deviations for both high and receding water phases.

\begin{tabular}{lcc}
\hline \multicolumn{1}{c}{ Variables } & High water & Low water \\
\hline Air temperature $\left({ }^{\circ} \mathrm{C}\right)^{*}$ & 33 & 35.3 \\
Precipitation $(\mathrm{mm})^{* *}$ & 120 & 0 \\
Total sun irradiation $(\mathrm{h})^{* * *}$ & 77 & 202 \\
Euphotic zone $(\mathrm{m})$ & $2.7( \pm 0.9)$ & $2.29( \pm 2.25)$ \\
$\mathrm{pH}$ & $6.74 \pm 0.23$ & $7.76( \pm 0.88)$ \\
Conductivity $\left(\mu \mathrm{S} . \mathrm{cm}^{-1}\right)$ & $45( \pm 9)$ & $43( \pm 13)$ \\
Turbidity $(\mathrm{NTU})$ & $16.0( \pm 10)$ & $82.9( \pm 75)$ \\
Dissolved oxygen $(\%$ saturation) & $61( \pm 15)$ & $134( \pm 30)$ \\
Water temperature $\left({ }^{\circ} \mathrm{C}\right)$ & $28.76( \pm 0.65)$ & $30.62( \pm 0.56)$ \\
Chlorophyll concentration $\left(\mu \mathrm{gg} . \mathrm{L}^{-1}\right)$ & $2.39( \pm 1.5)$ & $29.7( \pm 35)$ \\
\hline
\end{tabular}

${ }^{*}$ Monthly average; ${ }^{* *}$ Total rainfall; ${ }^{* * *}$ Number of sunny hours in a month. Data from Inmet (2010).

Table 2. Pytoplankton species richness at the Class taxonomic level for the Lower Amazon Floodplain (Brazil), during high and low water levels.

\begin{tabular}{lccc}
\hline \multirow{2}{*}{ Classes } & \multicolumn{3}{c}{ Taxa } \\
\cline { 2 - 4 } & High water & Low water & Total \\
\hline Bacillariophyceae & 9 & 12 & 15 \\
Chlorophyceae & 14 & 23 & 31 \\
Cryptophyceae & & 2 & 2 \\
Crysophyceae & & 1 & 1 \\
Cyanophyceae & 4 & 22 & 22 \\
Euglenophyceae & & 1 & 1 \\
Total & 27 & 61 & 72 \\
\hline
\end{tabular}

for Batata lake, located in the south bank of the Trombetas River, $100 \mathrm{~km}$ from our site. This river is a tributary of the Amazon River, with its confluence located in the center of the presently studied area. Nogueira et al. (2010) also reported a higher total of taxa for the Curuai lake floodplain (156) for their high water samplings in two consecutive years, reaching 122 taxa in 2002 and only 66 taxa in 2003. Curuai is one of the largest lakes within the presently study area.

The individuals documented during the 2009 high water season varied from 1 to a maximum of 7 taxa per sample in 2009 (Figure 5). Nogueira et al. (2010) reported a maximum of 47 taxa and a minimum of 2 taxa during the 2002/2003 water level period.

The small number of taxa observed for 2009 high water in the present study could be explained by very high dilution, caused by the increased discharge associated with the extreme flooding event, easily noticeable when comparing the maximum water level of the three hydrological years (2002 and 2003 from Nogueira's study and 2009 from the present study) (Figure 6). During 2009, higher water levels were observed not only during peak season, but also for the entire period previous to field sampling. Such high water levels probably led to higher and longer connectivity among lakes, lowering water residence times and increasing the rate of downstream nutrient export. This behavior is common in floodplain lakes, which tend to behave like lotic systems during the rising water phase (Lews and Hamilton, 1987; Lesack and Melack, 1995).

During the high water period, Chlorophyceae species dominated the phytoplankton communities in the lower Amazon, including 14 species with densities ranging from 10 to 102 ind. $\mathrm{mL}^{-1}$, and corresponding to $46 \%$ of the total number of species (Table 3). During the low water phase, communities were dominated by Cyanophyceae species (49\%), with high specific richness and densities ranging from 10 to 103 ind. $\mathrm{mL}^{-1}$. Ibanez (1998) reported higher densities for both high (102 ind. $\left.\mathrm{mL}^{-1}\right)$ and low water (103-105 ind. $\mathrm{mL}^{-1}$ ) seasons in Camaleão Lake. The observed community structure was also different, being dominated by Cyanophyceae during high water periods and by Euglenophyceae during the 1987 low water season and Bacillariophyceae during the 1989 low water season. Specific richness in Camaleão Lake was smaller than the observed for the present study, with 18 to 21 taxa during low 


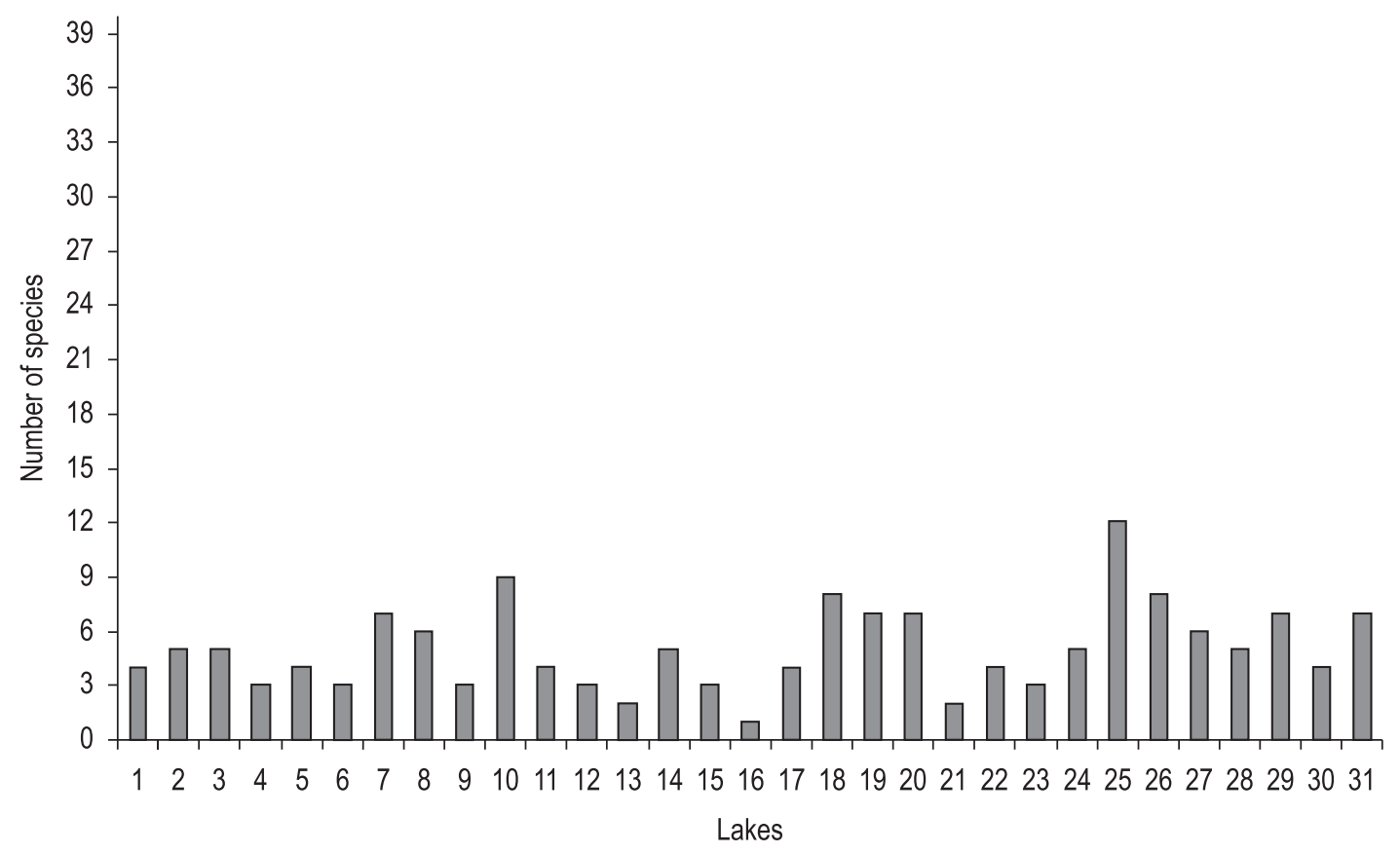

Figure 5. Phytoplankton species richness in lakes sampled during 2009 high water at the Lower Amazon River floodplain (Brazil).

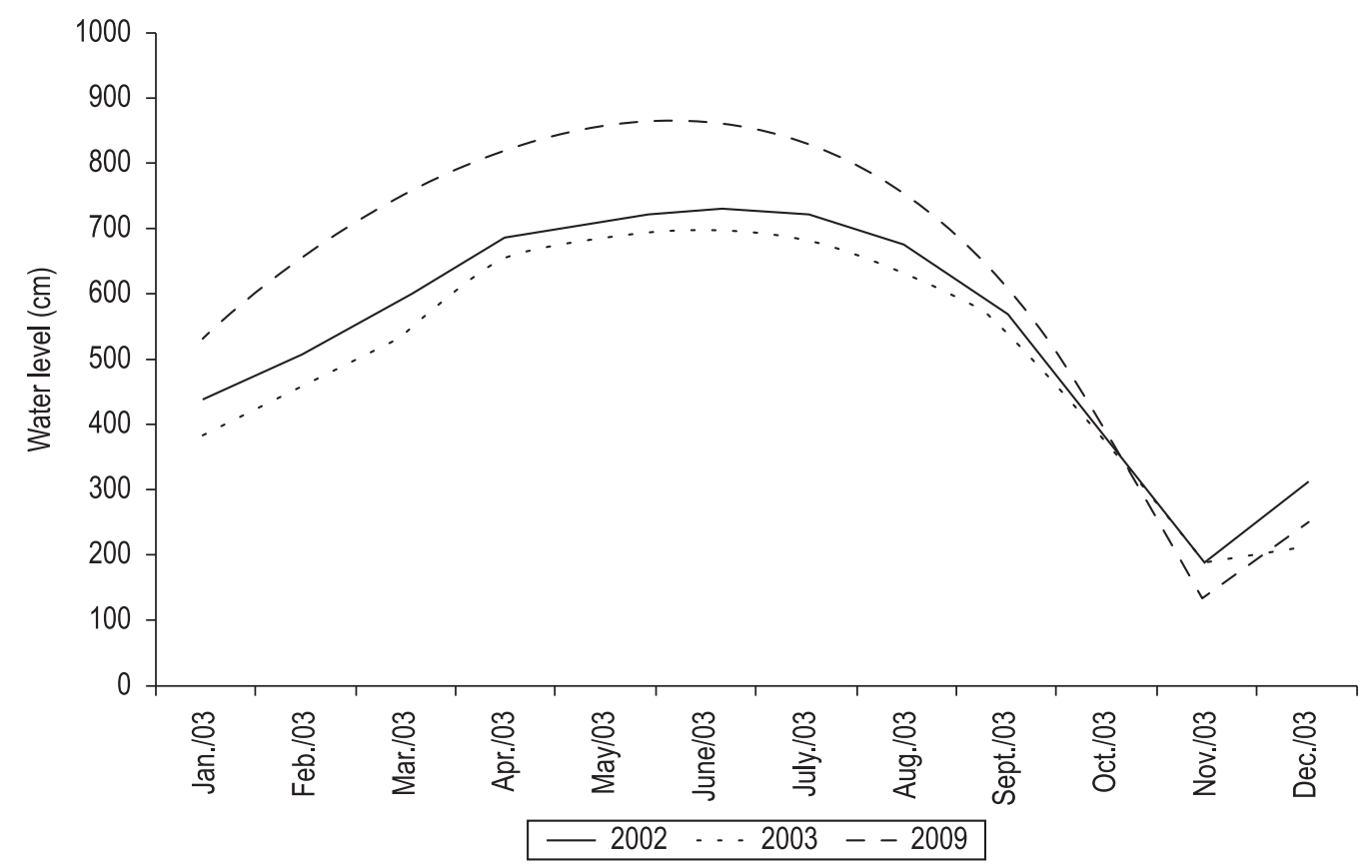

Figure 6. Maximum monthly water level for the Lower Amazon River for the Óbidos gauging station (Pará, Brazil), for the years 2002, 2003 and 2009.

water phases and only 3 taxa during the high water phase. Shannon diversity index values were similar for both high and low water phases $\left(-3.5\right.$ bits.ind $\left.^{-1}\right)$, both indicating high diversity, but not as high as reported by Melo and Huszar (2000) for Batata Lake (4.4-4.9 bits.ind $\left.^{-1}\right)$.
The analysis of relative phytoplankton density (Figure 7) revealed large differences in phytoplankton class distribution. During the high water season, Cryptophyceae had the largest relative density, with a single taxa (Cryptomonas) responding for $46 \%$ of the individuals. During low water, the 
highest relative density was evenly split between Bacillariophyceae (31\%) in which Aulacoseira was the most abundant taxa and Cyanophyceae (30\%) in which Dolichospermum circinalis, was the most abundant (Wacklin et al., 2009).

The abundance of Aulacoseira in phytoplankton communities has been related to low growth thresholds for light (Reynolds, 2006), and also to high amounts of particulate and dissolved organic carbon (DOC), again due to its effect on underwater irradiance distribution (Hammer et al., 2002). Alcântara et al. (2010) observed high turbidity values due to wind mixing effects during the low water phase for Curuai Lake, one of the larger lakes in the presently studied region, which could explain the observed Aulacoseira dominance.

Melo and Huszar (2000) study of diel variations and species adaptation strategies in Batata Lake indicated that hydrological and hydrographical properties defined the variations in phytoplankton

Table 3. Phytoplankton groups density (ind. $\mathrm{mL}^{-1}$ ) during high and low water level, for the Lower Amazon Floodplain (Brazil).

\begin{tabular}{lcc}
\hline \multicolumn{1}{c}{ Phytoplankton } & \multicolumn{2}{c}{ Phytoplankton density (ind. $\mathrm{mL}^{-1}$ ) } \\
\cline { 2 - 3 } \multicolumn{1}{c}{ groups } & High water & Low water \\
\hline Bacillariophyceae & 1389 & 22055 \\
Cyanophyceae & 750 & 26511 \\
Chlorophyceae & 1865 & 4441 \\
Cryptophyceae & 3927 & 631 \\
Crysophyceae & 221 & 192 \\
Dynophyceae & 720 & 0 \\
Euglenophyceae & 501 & 138 \\
\hline
\end{tabular}

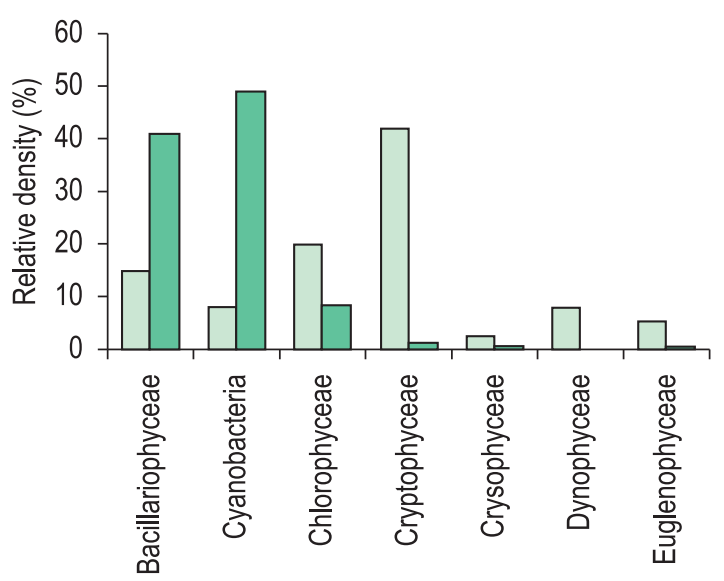

Phytoplankton group

$\square$ High water $\square$ Receding / Low water

Figure 7. Phytoplankton relative density (\%) during high and receding/low water period, for sampled lakes in the Lower Amazon Floodplain (Brazil). biomass and composition. The authors also related the annual cycle of water level fluctuation to the cycles of presence and absence of stratification in the water column. According to them, this imposed strong environmental seasonality to the lake, minimizing the impact of factors such as temperature and irradiance.

The present results suggest, however, that at least under extreme water level fluctuations as those observed for 2009, changes in water level can indeed induce shifts in phytoplankton community structure. During the high water, dilution processes and large inputs of dissolved organic matter impaired nutrient and light availability (Costa et al., 2011) respectively what might explain the sparser phytoplankton communities, characterized by smaller specific richness, lower density and lower relative density. During low water, hydraulic residence time varied locally as a function of lake connectivity to main rivers and channels. Lake size and depth also varied, and lakes could be differently affected by winds according to depth, making local factors more important for explaining species richness (Garcia de Emiliani, 1997).

The dominance of Cyanophyceae during low water may be related to lower light requirements related to phycobillin pigments (Shapiro, 1990; Dokulil and Teubner, 2000). In the present study, the species with the highest density was Dolichospermum circinalis. The absolute density of phytoplankton classes was smaller during high water (Table 4), and in the range reported for other floodplain lakes such as Camaleão Lake $\left(10^{2}\right.$ ind. $\left.\mathrm{mL}^{-1}\right)$ in Ibanez (1998), Batata Lake $\left(10^{3}\right.$ ind. $\left.\mathrm{mL}^{-1}\right)$ in Melo and Huszar, (2000). Low water level densities, however, were higher $\left(5,38 \times 10^{4}\right.$ ind. $\left.\mathrm{mL}^{-1}\right)$ than those measured by Melo and Huszar (2000) at Batata Lake $\left(11 \times 10^{3}\right.$ ind. $\left.\mathrm{mL}^{-1}\right)$. Considering that nutrients stored in the lake bottom may be inaccessible in the presence of stratification, as the water level decreases and the entire water column mixes, nutrient inputs from resuspension can be a key factor controlling phytoplankton abundance during the low water period.

Table 4. Dominant classes, species number and density of the phytoplankton community during the extreme water level condition for the lower Amazon River floodplain.

\begin{tabular}{lcc}
\hline & High water & Low water \\
\hline Dominant classes & Chlorophyceae & Cyanophyceae \\
Species richness & 14 & 22 \\
Density & $9.3 \times 10^{3}$ & $5,38 \times 10^{4}$ \\
\hline
\end{tabular}




\section{Conclusions}

Due to the limited number of studies about phytoplankton communities carried out in the Amazon floodplain region, the present research represents a valuable contribution to its characterization under extreme hydrological events. Changes in phytoplankton communities were observed in the Lower Amazon floodplain between high and low water. These changes were related to the flood pulse intensity, which modulates the limnological parameters, specifically the euphotic zone depth. Phytoplankton density was lower during the high water period, mostly caused by the dilution resulting from exceptional water level and above normal precipitation. During this phase, Cryptophyceae species were the more abundant ( $42 \%$ of total phytoplankton), followed by Chlorophyceae with $20 \%$.

During the receding water phase, higher values of turbidity were observed, resulting in shallower euphotic zone depths. Cyanophyceae species had the highest density, followed by Bacillariophyceae, both representing $90 \%$ of the population. These results show that, at least under extreme water level fluctuations such as those observed for 2009, changes in water level resulted in marked shifts in phytoplankton community structure and diversity.

\section{Acknowledgments}

The authors would like to thank the Fundação de Amparo à Pesquisa do Estado de São Paulo (FAPESP) (Project 08/07537-1), and to Conselho Nacional de Desenvolvimento Científico e Tecnológico (CNPq - Projects 477885/2007-1 and 550373/2010-1).

\section{References}

AFFONSO, A G., BARBOSA, C. and NOVO, EMLM. 2011. Water quality changes in floodplain lakes as a function of the Amazon River flood pulse: Lago Grande de Curuaí (Pará). Brazilian Journal of Biology, vol. 71, no. 3, p. 601-610.

ALCÂNTARA, EH. 2006. Análise da turbidez na planície de inundação de Curuaí (PA, Brasil) integrando dados telemétricos e imagens MODIS/TERRA. São José dos Campos: Instituto Nacional de Pesquisas Espaciais. [Dissertação de Mestrado em Sensoriamento Remoto]. Available from: <http://urlib.net/sid.inpe. br/mtc-m17@80/2007/02.15.17.09>. Access in: 11 nov. 2011.

ALCâNTARA, E., NOVO, EMLM., STECH, J., LORENZZETTI, J., BARBOSA, C., ASSIREU, A. and SOUZA, A. 2010. A contribution to understanding the turbidity berhaviour in an Amazon floodplain. Hydrology and Earth System Sciences, vol. 14, p. 351-364. http://dx.doi.org/10.5194/ hess-14-351-2010

American Public Health Association - APHA. Standard methods for the examination of water and wastewater. Washington: Byrd Prepress Springfield, 2005.

BARBARISI, BF. 2010. Integração de imagens MODIS e de dados censitários na avaliação do impacto da pecuária sobre o estado trófico de sistemas aquáticos do baixo amazonas. São José dos Campos: Instituto Nacional de Pesquisas Espaciais. [Dissertação de Mestrado em Sensoriamento Remoto].

BARBOSA, CCF. 2005. Sensoriamento remoto da dinâmica de circulação da água do sistema planície de Curai/Rio Amazonas. São José dos Campos: Instituto Nacional de Pesquisas Espaciais. [Tese de Doutorado em Sensoriamento Remoto].

BARBOSA, CCF, NOVO, EMLM., MELACK, JM., GASTIL-BUHL, M. and PEREIRA-FILHO, W. 2010. Geospatial analysis of spatiotemporal patterns of $\mathrm{pH}$, total suspended sediment and chlorophyll-a on the Amazon floodplain. Limnology, vol. 11, no. 2, p. 155-166. http://dx.doi.org/10.1007/ s10201-009-0305-5

BATES, PD., MARKS, KJ. and HORRITT, MS. 2003. Optimal use of highresolution topographic data in flood inundation models. Hydrological Processes, vol. 17, p. 537-557. http://dx.doi.org/10.1002/ hyp. 1113

BONNET, MP., BARROUX, G., MARTINEZ, JM., SEYLER, F., MOREIRA-TURCQ, P., COCHONNEAU, G ; MELACK, JM., BOAVENTURA, G., MAURICE-BOURGOIN, L., LEÓN, JG., ROUX, E., CALMANT, S., KOSUTH, P., GUYOT, JL. and SEYLER, P. 2008. FloodpLain hydrology in an Amazon floodplain lake (Lago Grande de Curuaí). Journal of Hydrology, vol. 349, no. 1-2, p.18-30.

COLE, GA. Textbook of limnology. Sant Louis: Mosby Company, 1975. 427p.

COSTA, M., NOVO, EMLM. and TELM ER, K. 2011. Spatial and Temporal Variability of Light Attenuation in Large Rivers of the Amazon. Freshwater Biology, submitted.

DOKULIL, MT. and TEUBNER, K. 2000. Cyanobacterial dominance in lakes. Hydrobiologia, vol. 438, no. 1-2, p. 1-12.

GARCIA DE EMILIANI, MO. 1997. Effects of water level fluctuations on phytoplankton in a riverfloodplain lake system (Parana River, Argentina). Hydrobiologia, vol. 357, p. 1-15.

HAMMER, A., SCHUMANN, R. and SCHUBERT, H. 2002. Light and temperature acclimation of Rhodomonas salina (Cryptophyceae): photosynthetic 
performance. Aquatic Microbial Ecology, vol. 29, p. 287-296. http://dx.doi.org/10.3354/ame029287

HENRY, R., USHINOHAMA, E. and ROSA, MRF. 2006. Fitoplâncton em três lagoas marginais ao Rio Paranapanema e em sua desembocadura no Reservatório de Jurumirim (São Paulo, Brasil) durante um período prolongado de seca. Revista Brasileira de Botânica, vol. 29, no. 3, p. 399-414.

IBANEZ, MSR. 1998. Phytoplankton composition and abundance of a central Amazonian flood-plain. Hydrobiologia, vol. 362, p. 78-83.

Instituto Nacional de Meteorologia - INMET. Available from: <http://www.inmet.gov.br/>.

JUNK, W., BAYLEY, PB. and SPARKS, RG. The flood pulse concept in river floodplain system. Canadian Journal of Fisheries and Aquatic Sciences Special Publications, 1989, vol. 106, p. 110 -127.

JUNK, WJ., ed. The central Amazon floodplain. New York: Springer-Verlag, $1997.530 \mathrm{p}$.

JUNK, W. and PIEDADE, MT. Plant life in the floodplain with special reference to herbaceous plants. In JUNK, WJ., ed. The central Amazon floodplain. New York: Springer-Verlag, 1997. 530 p.

LEWS, WM. and HAMILTON, SK. 1987. Causes of seasonality in the chemistry of a lake on the Orinoco River floodplain, Venezuela. Limnology and Oceanography, vol. 32, no. 6, p. 1277-1290. http:// dx.doi.org/10.4319/lo.1987.32.6.1277

LESACK, LFW. and MELACK, JM. 1995. Flooding Hydrology and Mixture Dynamics of Lake Water Derived from Multiple Sources in an Amazon Floodplain Lake. Water Resources Research, vol. 31, no. 2, p. 329-345. http://dx.doi. org/10.1029/94WR02271

LOVERDE-OLIVEIRA, SM. and HUSZAR, VLM. 2007. Phytoplankton ecological responses to the flood pulse in a Pantanal lake, Central Brazil. Acta Limnologica Brasiliensia, vol. 19, no. 2, p. 117-130.

KRUK, C., HUSZAR, VLM., PEETERS, ETHM., BONILLA, S., COSTA, L., LÜRLING, M., REYNOLDS, CS. and SCHEFFER, M. 2010. A morphological classification capturing functional variation in phytoplankton. Freshwater Biology, vol. 55, p. 614-627. http://dx.doi.org/10.1111/ j.1365-2427.2009.02298.x

MARENGO, JA., TOMASELLA, J., SOARES, WR., ALVES, LM. and NOBRE, CA. 2011. Extreme climatic events in the Amazon basin: climatological and hydrological context of previous floods. Theoretical and Applied Climatology, vol. 85, p. 1-13.

MCGRATH, DG., ALMEIDA, OT. and MERRY, FD. 2007. The Influence of Community Management Agreements on Household Economic Strategies: Cattle Grazing and Fishing Agreements on the Lower Amazon Floodplain. International Journal of the Commons, vol. 1, no. 1, p. 67-87.
MELO, S., and HUSZAR, VLM. 2000. Phytoplankton in an Amazonian flood-plain lake (Lago Batata, Brasil): diel variation and species strategies. Journal of Plankton Research, vol. 22, no. 1, p. 63-76. http:// dx.doi.org/10.1093/plankt/22.1.63

NABOUT, JC., NOGUEIRA, IS. and OLIVEIRA, LG. 2006. Phytoplankton community of floodplain lakes of the Araguaia River, Brazil, in the rainy and dry seasons. Journal of Plankton Research, vol. 28, no. 2, p. 181-193.

NOGUEIRA, IS., NABOUT, JC., IBANEZ, MSR. and BOURGOIN, LM. 2010. Determinants of beta diversity: the relative importance of environmental and spatial processes in structuring phytoplankton communities in an Amazonian floodplain. Acta Limnologica Brasiliensia, vol. 22, n. 3, p. 247-256. http://dx.doi.org/10.4322/actalb.02203001

NOVO, EMLM., BARBOSA, CCF., FREITAS, RM., Shimabukuro, YE., Melack, JM. and Pereira-Filho, W. 2006. Seasonal changes in phytoplankton distribution in floodplain lakes in response to Amazon flood pulse derived from MODIS images. Limnology, vol. 7, no. 3, p. 153-161.

NUSH, EA. 1980. Comparison of different methods for chlorophyll and phaeopigment determination. Archive fur Hydrobiologie Ergenebisse der Limnologie, vol. 14, p. 14-39.

ODUM, EP. Ecologia. Rio de Janeiro: Guanabara, 1988. 434 p.

RENÓ, VF. 2010. Avaliação do desflorestamento da várzea do Baixo Amazonas nas décadas de 1970 e 2000 a partir de imagens Landsat. São José dos Campos: Instituto Nacional de Pesquisas Espaciais. [Dissertação de Mestrado em Sensoriamento Remoto].

REYNOLDS, CS. 2006. The ecology of phytoplankton. Cambridge: New York. 535 p.

ROLAND,F., ESTEVES,F.A. and BARBOSA,F.A. 1997. The influence of the bauxite tailings on the light and its consequence on the phytoplankton primary production in an Amazonian flood-plain lake. Verhandlungen des Internationalen Verein Limnologie, vol. 26, p. 765-767.

ROOSEVELT, AC. 2000. The Lower Amazon: a dynamic human habitat. In: LENTZ, DL., ed. Imperfect Balance: Landscape Transformations in the PreColumbian Americas. New York. p. 455-491.

SHAPIRO, J. 1990. Current beliefs regarding dominance by blue- greens: The case for the importance of $\mathrm{CO} 2$ and $\mathrm{pH}$. Internationale Vereinigung fur Theoretische und Angewandte Limnologie, vol. 24, p. 38-54.

SHEIKH, PA., MERRY, FD. and MCGRATH, DG. 2006. Water buffalo and cattle ranching in the Lower Amazon Basin: Comparisons and conflicts. Agricultural Systems, vol. 87, p. 313-330. http:// dx.doi.org/10.1016/j.agsy.2005.02.003 
SILVA, TSF., COSTA, MPF. and MELACK, JM. 2010. Spatial and temporal variability of macrophyte cover and productivity in the eastern Amazon floodplain: a remote sensing approach. Remote Sensing of Environment, vol. 114, p. 1998-2010. http://dx.doi. org/10.1016/j.rse.2010.04.007

STRAATSMAA, M., and MIDDELKOOPA, H. 2007. Extracting structural characteristics of herbaceous floodplain vegetation under leaf-off conditions using airborne laser scanner data. International Journal of Remote Sensing, vol. 28, no. 11, p. 2447-2467. http:// dx.doi.org/10.1080/01431160600928633

UHELINGER, V. 1964. Étude statisque des méthodes de dénobrement planctonique. Archives des Sciences, vol. 17, p. 121-123.

UTHERMÖHL, H. 1958. On the perfecting of quantitative phytoplankton method. International Association of Theoretical and Applied Limnology Commun, p. 9-38.

WACKLIN, P., HOFFMANN, L. and KOMAREK, J. Nomenclatural validation of the genetically revised cyanobacterial genus Dolichospermum (RALFS ex BORNET et FLAHAULT) comb. nova. Fottea, vol. 9, p. 59-64. 2009.
WETZEL, RG. and LIKENS, GE. Limnological analysis. New York: Springer-Verlag, 1991. 391 p.

WINKLERPRINS, AMGA. 2006. Jute cultivation in the lower Amazon, 1940-1990: an ethnographic account from Santarém, Pará, Brazil. Journal of Historical Geography, vol. 32, no. 4, p. 818-838.

WITTMANN, F., SCHÖNGART, J., MONTERO, JC., MOTZER, T., JUNK, WJ., PIEDADE, MTF,, QUEIROZ, HL. and WORBES, M. 2006. Tree species composition and diversity gradients in whitewater forests across the Amazon Basin. Journal of Biogeography, vol. 33, no. 8, p. 1334-1347. http:// dx.doi.org/10.1111/j.1365-2699.2006.01495.x

WINTER, JG., YOUNG, JD., LANDRE, A., STAINSBY, E. and JARJANAZI, H. 2011. Changes in phytoplankton community composition of Lake Simcoe from 1980 to 2007 and relationships with multiple stressors, Journal of Great Lakes Research, vol. 37, no 3, p. 63-67.

VOLLENWEIDER, RA., ed. A Manual on Methods for Measuring Primary Production in Aquatic Environments. 2th edn. Oxford: Scientific Publishers, 1974. 